\title{
Re-interpretation of the classical geopolitical theories in a critical geopolitical perspective
}

\author{
HU Zhiding ${ }^{1,2}$, LU Dadao ${ }^{2}$ \\ 1. School of Tourism and Geography Science, Yunnan Normal University, Kunming 650500, China; \\ 2. Institute of Geographic Sciences and Natural Resources Research, CAS, Beijing 100101, China
}

\begin{abstract}
Struggling for supremacy between great powers and the rise or fall and regime change of great powers are all subject to the Geopolitical Law. Geographers should keep in step with the times, accurately grasp the national interests, and seize the opportunity to contribute to the great rejuvenation of our nation. However, due to lack of criticism on the history and philosophy of geopolitics, we can neither accurately understand the geopolitical theory, nor effectively put the geopolitical theory into practice. This paper introduces the development of critical geopolitics, summarizes the three characteristics of critical geopolitics, and interprets the four classical geopolitical theories accordingly. In order to simplify the interpretation process, this paper firstly presents an analytical framework for interpretation of four classical geopolitical theories; secondly, focuses on interpretation of "The Geographical Pivot of History" put forward by Mackinder according to the analytical framework; finally, critically summarizes the four classical geopolitical theories. Through the critical interpretation, this paper draws a conclusion that there are the scientific, hypothetical and conceptual classical geopolitical theories. The construction of classical geopolitical theories is based on the international geopolitical structure, spatial distribution of national interests and inter-state spatial conflict, in order to show the identity of theoretical constructor, so as to reflect the historicality, sociality, situationality and geographical knowledge - power structure of geopolitical theories.
\end{abstract}

Keywords: critical geopolitics; geopolitics; national organism theory; sea power theory; land power theory; edge district theory

\section{Introduction}

Throughout history, the rise of any country will cast influence on global stability and geopolitical structure (Hu et al., 2014). The rise to supremacy and decline of big powers are all subject to the laws of geopolitics. Since the end of the Cold War, with the rapid development of China and other emerging countries, the international power structure has been undergoing profound restructuring; the peaceful development of China urgently needs to be supported by geopolitics, geo-economics and other theories (Lu et al., 2013). Geography is the basis for

Received: 2015-10-03 Accepted: 2015-11-03

Foundation: National Natural Science Foundation of China, No.41401157, No.41661033

Author: Hu Zhiding (1986-), PhD and Associate Professor, specialized in globalization and geo-setting research. E-mail: huzhiding2007@126.com 
research on geopolitics and geo-economics. Therefore, Lu Dadao called for the geographers to keep up with the pace of the times, accurately grasp the national interests, seize the opportunity to make a contribution, especially submit the more forward-looking, holistic and speculative consultation report to the State based on a solid theoretical research, and demonstrate some opinions and suggestions on worldwide problems put forward by the geographical community to the public.

However, at present, in the study on geopolitical theories made by the domestic geographical circles, especially in the geo-strategic research, there may be a certain level of misunderstandings, as called by Ratzel, Mackinder, Mahan, Speakman and other early classical geo-strategic scholars, and guiding the China's geo-strategic practice with the help of their theories. In the application of classical geopolitical theory for guiding the geo-strategic practice, we often ignore a background of theory builders, blindly following the "immutability of truth" (Sun et al., 2006). Leslie Hepple clearly pointed out that, due to lack of criticism on the history and philosophy of geopolitics, we would easily make the same mistake (Hepple, 1986). Naturally, there still exist some disadvantages of China's geopolitical security situation analyzed and geo-strategy proposed only according to the classical geopolitical theory (Zhang, 1996; Wang, 2003; Du et al., 2012). Engels already clearly stated: "If a nation wants to stand at the forefront of science, it must have the theoretical thinking all the time. However, the theoretical thinking of every age is a kind of historical products, which has different forms and contents at different times." (Marx et al., 1971) Although there are differences in expression forms and research contents of early classical geopolitical theories (national organism theory, sea power theory, land power theory and edge district theory), every Geopolitical Theory proposed is one of the theoretical products required by the historical background and national reality at that time. Therefore, when learning from and making use of such classical geopolitical theories, we must understand comprehensively the scientific, hypothetical and conceptual levels of geopolitical theories, as any theory has its scientific aspect and its hypothetical aspect, and also is a natural expression of political ideas put forward by theoretic advocates (Wang et al., 2003). Social scientists cannot get rid of their social and historical identities. The social knowledge they have proposed is always one-sided, has one viewpoint, and draws out the meanings of special moral and ideology.

Under the influence of postmodernism, especially the knowledge-power theory proposed by Michel Foucault, scholars of geopolitics have critically reconstructed geopolitics, thereby resulting in the birth of critical geopolitics (Chen et al., 2012). Through reflection on the ontology, epistemology and intellectual history of traditional geopolitics, critical geopolitics can carry out the doubt and criticism on some basic logics and hypotheses of traditional theory (Ge, 2010a). From the point of view of critical geopolitics, this paper intends to critically review and reflect the construction process of classical geopolitical theories, and restore the historicality, sociality, situationality and inclusive power - knowledge structure of classical geopolitical theories. This paper can be broadly divided into three parts: Part I: Overview of the development of critical geopolitics, focusing on summarizing its main characteristics; Part II: Deconstruction of classical geopolitical theories by learning from and making use of critical geopolitical thoughts; Part III: Conclusion and discussion. 


\section{Development of critical geopolitics and its characteristics}

\subsection{Development of critical geopolitics}

The origins of critical geopolitics can be traced back to the 1970s. However, this term "critical geopolitics" was created by three political geographers (Gearóid Ó Tuathail, John Agnew and Simon Dalby) in the early 1990s (Ó Tuathail et al., 1992; Dalby, 1991a, 1991b). The critical geopolitics came into being due to the following main three reasons: (1) changes in pattern of Geopolitics after the Cold War; (2) uniquely-divided research field driven by desire; (3) sense of responsibility undertaken by many English-speaking scholars who deeply felt that it was necessary to correlate the ideas with political practice in the post-Cold War years (Dodds, 2001). As a bridge for currently communicating geography with international relations, due to the influence and inspiration by Michel Foucault and Jacques Derrida, the critical geopolitics has been defined as the combination of a series of political discourses, statements and practices, rather than a term simply describing the relationship between geography and politics (Ó Tuathail, 1986). Therefore, the critical geopolitics is not aimed to be committed to the development of theory in the interaction between space and politics, but focuses on deconstructing the geopolitics discourse and disclosing the power relationships hidden in the discourse, geographical knowledge and other events, especially challenging all kinds of global spatial maps made by the militants (Marcus et al., 2010).

The development of critical geopolitics has benefited from a lot of research work undertaken by geographers and international relation scholars, involved in political identification, conflict geographical consequences, philosophy, political practice and other themes raised during the Cold War, and importantly supported by post-structuralism and political economics (Petter et al., 1985; Murphy, 1997). Critical geopolitics is not a denial of traditional geopolitics, but a complement to the understanding of "politics" and "geography". Therefore, critical geopolitics can be seen as a different form of geopolitics being formed. However, there is still a dispute on the use of the term "critical geopolitics". When attending a meeting on "New Directions for Research on Critical Geopolitics" organized by AAG (American Geographical Society) in 2007, Neil Smith pointed out that, the term "critical geopolitics" was suspected of being improperly used, which was just one of the main reasons for holding the meeting at that time (Jones et al., 2010). Otto Wasser (the pioneer of critical geopolitics) more directly pointed out that, the term "critical geopolitics" was created only for the sake of convenience (Dalby, 2010).

The main directions of criticism of critical geopolitics shall be as follows: (1) criticize the research conducted beyond the text; restore the situational practice of geopolitics; the practice of geopolitics has been regarded as an objective and actual practice in early stages; (2) criticize the country-centered research on the world's politics; restore the practice of different behavior subjects in the international geopolitics system; (3) criticize the Western-centrism; clarify the influence of Western geopolitics scholars and their discourses on the key historical development (Ó Tuathail, 1996). Therefore, the critical geopolitics scholars consider that, geopolitics is a broad cultural phenomenon, and its behavior subject is not single but diverse, and its value is not politically neutral. However, for a long time, since critical geopolitics has been excessively dominated by textualism research methods, research on conceptualization \& theorization of discourse and construction of critical geopolitical theory is far from enough 
(Müller, 2008). Meanwhile, although critical geopolitics has shaken the state-centrism, no opposing revolutionary methods have been proposed for understanding and investigating geopolitics. Currently, some geographers have carried out related exploration into this subject (Passi, 2000, 2006; Megoran, 2006).

Affected by the definition, objectives and critical direction of critical geopolitics, the research on critical geopolitics can be broadly divided into four research subjects, namely Geopolitics Practice, Geopolitics Tradition, Geopolitics and Popular Culture, and Structural Geopolitics (Dodds, 2001). Geopolitics Practice refers to understanding of the geographical and political logics, propagation as well as the world's political practice conditions, mainly focusing on re-thinking about the national spatial morphology (Ó Tuathail, 1966). Geopolitics Tradition refers to review of the historical and geographical background on geographical, political, strategic and other thoughts, mainly focusing on the interpretation of traditional Geopolitical thought texts, e.g. Analysis of the Impact of European Uncertain Academic and Political Climate on Development of Geopolitics Thought (Michael Heffernan), Analysis of the Role and Significance of Italian Geopolitics Imagination on Construction of Nation-State (David Atkinson), Geopolitics Practices of Ensuring the Food Security in China (Alana Boland), and Discussion on the Relationship between Geographical Imagination and Geopolitics in Argentina (Klaus Dodds) (Dodds, 2000; Boland, 2000). The study on Geopolitics and Popular Culture remarks that we have made great efforts in the practices of removing the "state-centrism" and restoring different behavior subjects, e.g. Study on Cold War and Magazine (Joanne P. Sharp), Study on Cartoon and Anti-terrorism War (Dodds), Study on Film and Geopolitics (Michael Shapiro), Study on Radio Broadcast and Geopolitics (Alasdair Pinkerton), etc. (Sharp, 2000; Dodds, 2008; Shapiro, 2008; Pinkerton et al., 2009). The study on Structural Geopolitics refers to the combination of governing practice and globalization, information network, economic transition, etc. (Luke et al., 1997).

In addition, after the end of the Cold War, the world has not entered into a new, democratic and peaceful society. As a result of wars that have broken out in Bosnia, Kosovo, Chechnya and other regions, the conflict research on critical geopolitics has been strengthened once more (Reuber, 2000). The conflict research subjects shall mainly include six aspects, i.e., ecological politics and resource conflicts (Momtaz, 1996), territorial conflicts and boundary (Gachechiladze, 1997), geopolitics and political identification (Fenster, 1996), globalization and new state relations (Wood et al., 1993), symbolic representation of political rights (Cosgrove, 2008), and regional conflicts and new social movements (Watts et al., 1993). The emotional factors of human behavior are becoming key fields for the research on critical geopolitics, e.g. Emotion and Invasion of Iraq (Ó Tuathail, 2003), Movies and Emotional Logic of Intervention (Sidaway, 2009), Geopolitics, Emotion and Place (Sidaway, 2009), and Emotion and Security Practices (Anderson, 2010). In 2007 and 2008, the conferences on critical geopolitics were held, respectively. Some research scholars questioned and expressed their dissatisfaction with the research on critical geopolitics at that time. Under the influence of both factors, the theoretical research on critical geopolitics has been strengthened, which especially focuses on the discussion on "discourse", "geography" and "politics", and emphasizes theoretical improvement and other aspects (Martin, 2008; Hyndman, 2010).

\subsection{Characteristics of critical geopolitics}

Under the influence of postmodernism, critical geopolitics has the following three significant 
characteristics: (1) situationality of Geopolitical Theory and diversification of viewpoint, i.e., social and historical contexts of builder; the connotation of geopolitics can be determined by the location and viewpoint of observer; (2) geopolitics is not objective and neutral; the theory or idea of geopolitics has its value targets and political pursuits; (3) the knowledge and theory of geopolitics can reflect the discursive power relationship and discursive political connotation (Sun, 2006). When reviewed from a post-modernist point of view, "geography" is diversified with different meanings. Geography is an inevitable social and political "geographing", a kind of earth-writing as well as a cultural and political writing of worldwide significance. Similarly, geopolitics is a writing of national political and geographical significance (Ó Tuathail, 1999). Thus, geopolitics is no longer neutral and objective research on observation of global space, but the preconditions for taking geopolitics itself as a geographical and political form, i.e. geopolitics has its contextual correlates, and contained in the real social reproduction of power and political economy (Ó Tuathail, 1998). Otto Wasser considered that, we could best understand the concept and theory of Geopolitics only through the historicality and situationality, because Geopolitics was involved in a writing of global space, while a kind of anti-universal method for knowledge exploration was required, through which Geopolitics was not considered as a stable single-dimensional and linear concept (Ó Tuathail, 1996).

\section{Interpretation of classical geopolitical theory from a critical perspective}

Inspired by the development of critical geopolitics and its characteristics, through the reflection on classical Geopolitical Theory by some domestic scholars (Huang et al., 2012; Ge, 2010b; Zhang, 2007), in accordance with the theoretical requirements for realizing China's peaceful rise, we must further interpret the classical Geopolitical Theory, understand the social and historical contexts of classical geopolitical theory builder, clearly put forward the value targets and political pursuits of theory, and get rid of the "immutability in truth outlook" of theory. Only this can correctly guide the use of classical Geopolitical Theory in order to propose the Geopolitical Theory adapted to Chinese national conditions for China's peaceful rise.

Classical Geopolitical Theories defined herein refer to "land power theory" (Mackinder), "sea power theory" (Mahan), "national organism theory" (Ratzel) and "edge district theory" (Speakman). It is almost impossible to conduct a comprehensive deconstructive interpretation of these four classical Geopolitical Theories in one paper. Therefore, the strategies proposed in this paper shall be as follows: present a framework of critical classical Geopolitical Theory based on critical geopolitics to adapt to the abovementioned four classical Geopolitical Theories; secondly, focus on the interpretation of "The Geographical Pivot of History" (Mackinder) based on this analytical framework; select the land power theory (Mackinder) in consideration of the overall influence and basic role of land power theory on the later important geo-strategic theories, e.g. edge district theory (Speakman), Grand Chessboard (Brzezinski), Diplomacy (Kissinger) and other theories considered as an extension of land power theory; finally, summarize classical Geopolitical Theories; analyze the four classical Geopolitical Theories; propose the sociality, historicality, situationality and political pursues \& powerknowledge structure, etc. Thus, the interpretation of the four classical Geopolitical Theories has formed. 


\subsection{Interpretation \& analytical framework}

The research on Classical Geopolitical Theory has two perspectives: spatial perspective and power perspective. These two perspectives are not only the starting point of interpretation of classical Geopolitical Theory, but also the basis of construction and interpretation of analytical framework. The power is not only an eternal subject of international politics, but also the primary cause of constituting and deciding the conflict and cooperation (Ye et al., 2008). Therefore, the power perspective can guide and analyze the change of strength between States and the short-board effect of individual state power. As one of the core concepts of geography, space has occupied a central position in geographical studies for a long time, thus having formed the spatial tradition of geographical research thereby $(\mathrm{Hu}, 2012)$. The spatial perspective can guide and analyze the spatial distribution of core national interests and the spatial conflict between States. In combination of spatial distribution of national interests, spatial conflicts between States, change of strength between States and short-board effect of individual state power, the main national geoborderunity in geopolitics can be defined, which constitutes macro-scale analysis.

After determining the main national geoborderunity, we can move on to meso-scale analysis, and focus on analysis of the relationship between States. The observer's viewpoint and theoretical value targets or political pursuits depend on the State where the theory builder resides. Finally, we can come down to micro-scale analysis, i.e., the theory builder. The theory will be put forward under the influence of theory builder's duty, academic background, personal preference, social background and other factors. The interpretation \& analytical framework of classical Geopolitical Theory is shown in Figure 1 below. Thus, we can understand the scientific, hypothetical and political ideas of classical Geopolitical Theory.

\subsection{Interpretation of geographical pivot of history (Mackinder)}

In order to interpret the four classical Geopolitical Theories, it is necessary to answer the following two questions: why did they propose their theories almost at the same time, i.e. "national organism theory" proposed by Ratzel for Germany, "land power theory" proposed by Mackinder for UK, and "sea power theory" proposed by Mahan for US? Why did Mackinder propose the land power theory (rather than sea power theory) for the UK? Why did Speakman change the sea power theory and propose the edge district theory for the US after the end of World War II? With these two questions, combined with the interpretation \& analytical framework of classical Geopolitical Theory, this paper has comprehensively investigated the global scale, regional scale and theory builder. Herein the authors only take "The Geographical Pivot of History" (Mackinder, 2011) as an example; the analysis ideas have been shown in this paper; the analysis of the other three classical Geopolitical Theories is presented in the theoretical summary section.

"The Geographical Pivot of History" proposed by Mackinder was read out to the British Royal Geographical Society on January 25, 1904. From 1500 to 1763, the world started to be unified. By 1763, the world's basic contours began to emerge, resulting in a global vision (Stavrianos, 2005). As a result of global unity, the global political and economic relations have undergone fundamental changes, and consequently, the world's balance of power has undergone tremendous changes as well. 


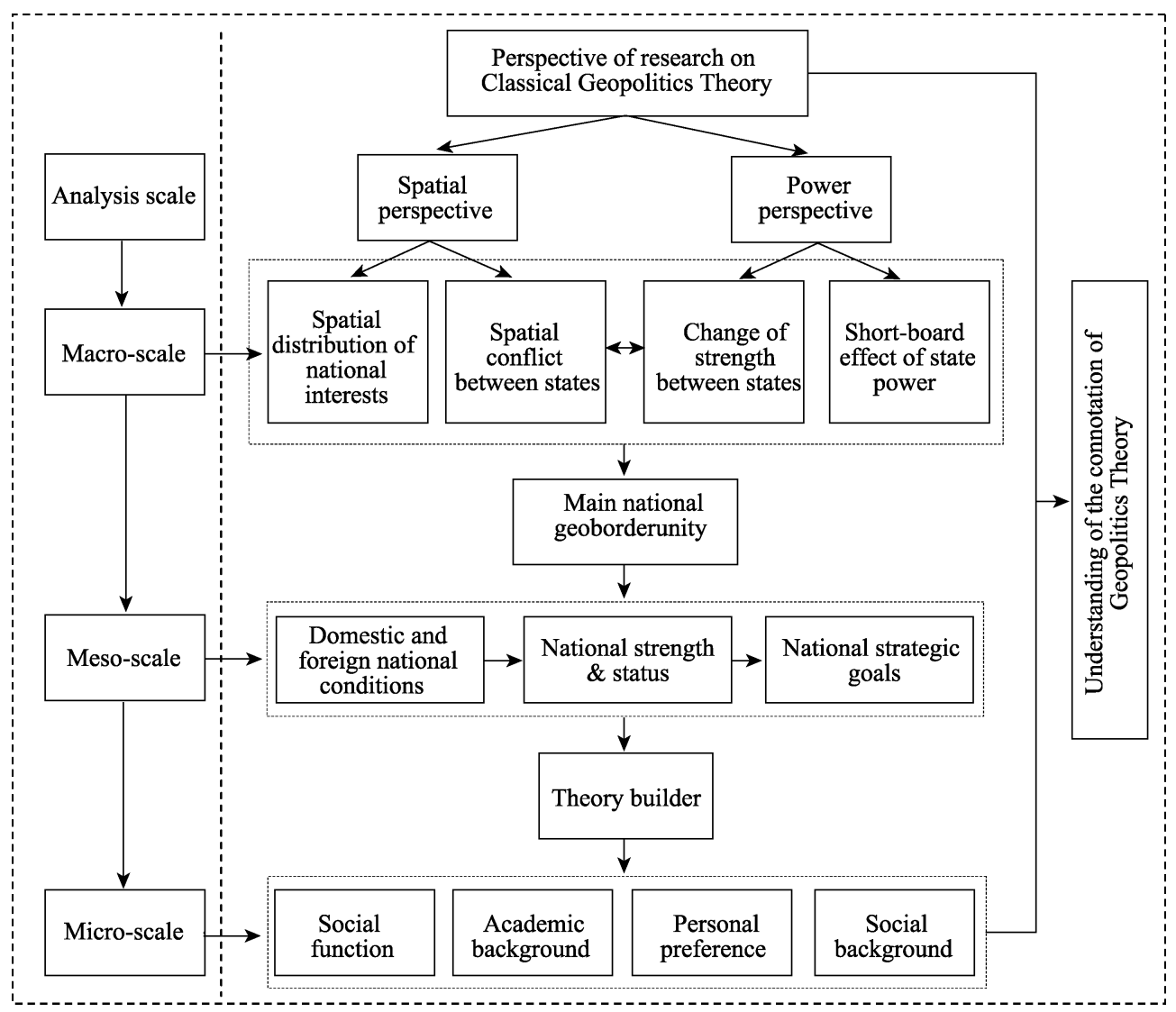

Figure 1 The analysis framework of classical geopolitical theory

As it could be seen from Table 1, from the 18th century to the 20th century, the geo-economic pattern of the world and between regions and countries had significantly changed. The ratio between the world's total GDP and the Western Europe's GDP was increased continuously. Among the Western European countries, the GDP of the United Kingdom (UK) was growing rapidly. The ratio between the world's total GDP and the Asia's GDP was decreased. The GDP of Japan, China and India was decreased to different extents. The GDP of the former Soviet Union and the United States (US) was increased more rapidly. From the ratio between the world's total GDP and the countries' GDP, in the world's geopolitical game theory, the main national geoborderunity was involved in nine countries as mentioned in Table 1. From 1783 (American Independence Day) to the end of the 19th century, its development could be roughly divided into three stages: Before 1861 (before the Civil War); 1861-1865 (during the Civil War); and 1865 (during the post-war period) (Ding, 2001). Therefore, before 1865, the spatial distribution of America's national interests and the spatial conflicts between states were mainly concentrated in North America. After 1865, the United States began to shift from continental expansion to overseas expansion, and from the spatial distribution of national interests and the spatial conflicts between States to worldwide movements.

By the end of the 19th century, national unity was the biggest issue that Germany was facing. Germany was unified as a Little German unified ethnically diversified nation successively by the German-Danish War (1864), the Austro-Prussian War (1866) and the Franco- 
Prussian War (1870-1871) (Li, 2005). Subsequently, Germany had experienced internal and external peaceful development for more than 40 years. Overpopulation was one of the main problems caused by the rapid economic development, which was particularly evident in Germany. Influenced by Social Darwinism, territorial expansion in Europe was considered as the only way to acquire the living space (Geoffrey, 1992). Therefore, for Germany, the spatial distribution of its national interests and inter-state conflicts were mainly concentrated in the neighboring countries.

Table 1 Major national and regional GDP share of world GDP, 1700-2009

\begin{tabular}{lcccccccc}
\hline \multicolumn{1}{c}{ Year } & 1700 & 1820 & 1870 & 1913 & 1950 & 1973 & 1998 & 2009 \\
\hline France & 5.7 & 5.5 & 6.5 & 5.3 & 4.1 & 4.3 & 3.4 & 3.0 \\
Germany & 3.6 & 3.8 & 6.5 & 8.8 & 5.0 & 5.9 & 4.3 & 4.0 \\
Italy & 3.6 & 3.8 & 6.5 & 8.8 & 3.1 & 3.6 & 3.0 & 2.5 \\
The United Kingdom & 2.9 & 5.2 & 9.1 & 8.3 & 6.5 & 4.2 & 3.3 & 3.1 \\
The Former Soviet Union & 4.4 & 5.4 & 7.6 & 8.6 & 9.6 & 9.4 & 3.4 & - \\
The United States & 0.1 & 1.8 & 8.9 & 19.1 & 27.3 & 22.0 & 21.9 & 20.4 \\
Japan & 4.1 & 3.0 & 2.3 & 2.6 & 3.0 & 7.7 & 7.7 & 6.0 \\
China & 22.3 & 32.9 & 17.2 & 8.9 & 4.5 & 4.6 & 11.5 & 12.6 \\
India & 24.4 & 16.0 & 12.2 & 7.6 & 4.2 & 3.1 & 5.0 & 5.1 \\
\hline
\end{tabular}

Data sources: Angus Maddison [British author]. History of Thousand Years of World Economy. Beijing: Peking University Press, 2010

From 1820 onwards, due to its technological progress and real income growth, the UK experienced accelerated development for a considerable long period. In 1783-1870, the British Empire kept growing with expansion. From the 19th to the 20th century, the British ruled over a vast empire, including the majority of North America, vast regions of the Caribbean Sea, vast land in the south of the Sahara Desert of Africa, the entire Indian Sub-continent and Australasia, Southeast Asia and Pacific regions, and even once controlled most regions in the Middle East (Marshall, 2004). Thus, the spatial distribution of Britain's national interest and inter-state conflicts were mainly concentrated in its overseas colonies, especially in Eurasia.

After two weeks of Mackinder's paper presentation, the Russo-Japanese War broke out. In the UK, it was a period of intense fear for Russia. Almost throughout the 19th century, the European powers did not pose a serious threat to the British Empire's properties. But the British Empire still worried about the rise of two countries - the US and Russia. We can see from the above analysis of the US that, although the total economy in the US was quite close to that of the UK by the end of the 19th century, American overseas expansion just started. The protection of British and American overseas interests depended on the national naval power, while the short-board effect of American state power was just dependent on its national naval power. In the 1880 s, the USN (U.S. Navy) was only a fleet consisting of 142 obsolete wooden structure vessels, excluding an ironclad warship, but including 12 large ocean-going ships. The British sailing boats \& steamships and shipping capacities almost accounted for nearly one-third of the world' total. The British naval power was far more than the US Navy power (Table 2). Therefore, the US did not constitute a deadly threat to the offshore national interests of the UK. 
Table 2 The UK and the world's marine shipping capacity, 1570-1913

\begin{tabular}{ccccccc}
\hline Time & Sailing boat & Steamship & $\begin{array}{c}\text { Total shipping } \\
\text { capacities }\end{array}$ & Sailing boat & $\begin{array}{c}\text { Steamship } \\
\text { Total shipping } \\
\text { capacities }\end{array}$ \\
\hline 1780 & 1000 & UK & & World \\
1820 & 2436 & 3 & 1000 & 3950 & 0 & 3950 \\
1850 & 3397 & 168 & 2448 & 5800 & 20 & 5880 \\
1900 & 2096 & 7208 & 4069 & 11400 & 800 & 14600 \\
1913 & 843 & 11273 & 40928 & 6500 & 22400 & 96100 \\
\hline
\end{tabular}

Note: Data sources: Angus Maddison. History of Thousand Years of World Economy, P.88

As the UK was absolutely a maritime hegemonic power, only those great powers attacking the British colonies by land would impose a real threat to the British Empire. Thus, Russia would become a real threat to the Britain's overseas national interests. In fact, from 1814 (failure of challenge to the UK and Europe by Napoleon) to 1914 (the World War I), the world plunged into the era of "Cold War" among great powers (i.e., Britain and Russia as the main rivals) lasting for 100 years. In order to deal with the threat from Russia, the British Empire sent troops for interference in Afghanistan in 1838 and 1842 so as to establish a pro-British regime, but suffered a complete defeat (Zhang, 2014). In 1873, the Russians controlled the last independent Khan regime (kava) in Central Asian. By 1884, Russia completely controlled the border regions of Afghanistan, and built a railway network there. The construction of such transport facilities provided powerful military supplies for Russia, so that Russia could easily launch an attack to India within a short range. In 1891, the Russians began to build the Great Siberia Railway, and asserted that Manchu (Northeast China) was their special sphere of influence. Relying on its powerful navy, the UK gradually extended its tentacles to all over the world, while Russia also gradually started to conquer the world depending on its overland railways. They became the main rivals who would contend for the world's "real estate" (Figure 2).

After analyzing the complete ball scale and regional scale, we started to analyze the theory builders. Halford John Mackinder, the author of "The Geographical Pivot of History", was born in Gainsborough Lincolnshire in 1861. In 1880, he went to the Oxford University to study natural sciences and modern history. In 1887, he read out the Scope and Method of Geography at the Royal Geographical Society of Great Britain, and obtained a five-year lecturer seat at Oxford University. In 1889, he was appointed as the Head of the First Department of Geography founded in Oxford University ${ }^{1)}$. Since undertaking the work of Oxford University Club, he always took an intense interest in politics. In 1904, he presented "The Geographical Pivot of History" in order to apply his geographical thoughts to politics. In virtue of his theoretical research on politics, he became a politician engaged in political activities. In 1900 and 1909, he participated in the City Council election twice. In 1919-1920, he served as a senior British official in southern Russia, and acted as a member of British Royal Income Tax Service Board \& Patented Invention Committee as well as the Chairman of British Empire Shipping Committee \& British Empire Economic Committee.

1) Data sources: E.W. Gilbert, Introduction to "The Geographical Pivot of History". 


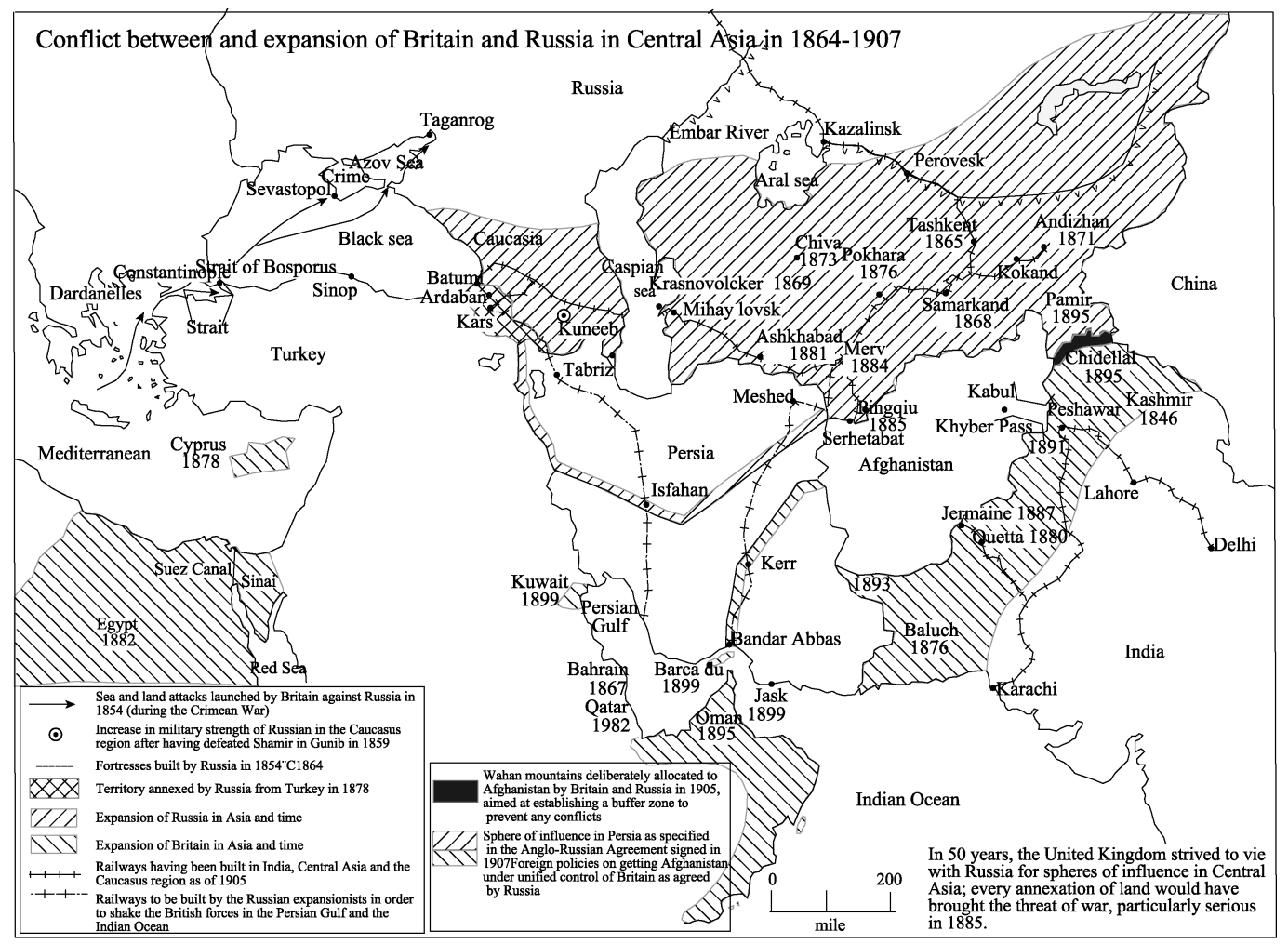

Figure 2 Britain and Russia conflict and expansion in Central Asia,1864-1907

Note: Data sources: Martin Gilbert [British author]. Wang Yuhan [translator]. Map of Russian History. Beijing: China Youth Press, 2012: 60

Therefore, in order to understand why Mackinder has proposed the "land power theory", it is necessary to combine his geographical thoughts with his political identity due to the "Hundred Years' Great Cold War" between Britain and Russia. In Scope and Method of Geography, Mackinder explained geography and political geography, as well as the relationship between the two disciplines. Mackinder defined geography as a science as follows: its main function was to explore the interaction between human beings in society and in the locally-changing environment. Meanwhile, Mackinder urged the necessity for "combining natural geography with political geography"; he pointed out that, if political geography was not based on natural geography, rational political geography could not exist. His thoughts were fully reflected in his land power theory. In "The Geographical Pivot of History", Mackinder pointed out: "I'm going to describe those natural characteristics of being the most coercive power on human actions; those natural characteristics have been organically combined with the history when they are not understood in geography, so that the history presents some of the key aspects". In addition, he pointed out that, under pressure of foreign barbarians, Europe was able to achieve its civilization. In a very real sense, European civilization was the result of a long struggle against the Asian invasion.

According to the description of overall development of the UK and the world before and after 1900, we can easily understand why Mackinder has put forward two propositions in the land power theory as his theoretical construction principle. The first proposition is that, the 
world is a whole, and then has become a complete political system; the second proposition is that, the recent expansion of Russia may be of extreme importance to the world. Therefore, in order to guide the UK to maintain its hegemony, and prevent Russian from posing a threat to Britain, Mackinder has put forward the concept of Eurasia and Heartland. Any ship could not reach the Eurasia as a vast continent. However, in ancient times, a herdsman on horseback could move about freely and quickly in Eurasia. Today, the region to be covered with the railways is the world's geo-political pivot area. Now, Russia has replaced the Mongol Empire, and will pose a greater threat to Finland, Scandinavia, Poland, Turkey, Persia, India and China than any attacks ever launched by the Mongol Empire. On account of expansion of pivotal countries to the marginal regions of Eurasia, the balance of power will be beneficial to Russia, so that Russia will be able to establish a fleet by taking advantage of the huge resources of this continent, and is thus likely to become the world empire. Therefore, in order to defend against this potential threat, France and the maritime powers will establish the Union; France, Italy, Egypt, India, and North Korea will become so many bridgeheads; the external navies of Britain, Japan, the United States and other countries can support land forces from these bridgeheads, in order to force the pivotal Union to also establish the land forces so as to prevent them from mobilizing all energies to create the fleet.

\subsection{Summary of the classical geopolitical theory}

The similar analysis can be also adapted to Ratzel's "national organism theory", Mahan's "sea power theory" and Speakman's "edge district theory". However, it must be noted that, there are differences between "National organism theory" and the other three theories. Such theories are at different levels of Geopolitical Theory System. The national organism theory refers to a theory on exploring the nature of state. The other three theories are at the geo-strategic levels. Through comparative analysis, we can answer the two questions as stated above: The first question: Why did Mackinder, Mahan and Ratzel propose the three different theories almost at the same time? From the perspective of critical geopolitics, there are several reasons behind the answer to this question: Firstly, there are background differences among theory builders. As a geographer, Mackinder is keenly interested in politics; moreover, as a geographer and politician, Mackinder has always emphasized the impact of geography on history. As a US Navy officer, Mahan has been heavily influenced by Ancient Greece Athens Navy Commander in Chief Themistocles and Politician Pericles; meanwhile, as a naval historian, Mahan has intensively studied the impact of sea power and sea supremacy on history. As a geographer, having received specialized training in biology, Ratzel is good at studying all political and geographical issues by means of biological evolutionary theory or biological analogy method. Secondly, the countries where the theory builders settle are faced with different problems. At that time, the problem faced by the UK was how to resist the threat of Russian expansion to its colonial rule; the problem faced by the US was how to ensure the safety of its overseas trade channels and enhance its international status; the problem faced by Germany was how to deal with the dramatic increase in population along with the rapid economic development after the national unity and enhance its international status. Thirdly, there are differences in the spatial distribution of national interest and the inter-state conflicts. At that time, the spatial distribution of Britain's national interests was mainly concentrated in its 
overseas colonies, especially geographical conflicts between Britain and Russia; the spatial distribution of American national interests began to shift from at home to abroad, especially maritime trade and transport security conflicts; the spatial distribution of Germany's national interests mainly concentrated on its surrounding regions, especially conflicts between Germany and its neighboring countries.

The second question: Why did Mackinder propose the land power theory (rather than sea power theory) for Britain (an island country)? Why did Speakman modify the sea power theory and put forward the edge district theory? The land power theory proposed by Mackinder for the island country was related to the spatial distribution of the Britain's national interests and inter-state conflicts. Meanwhile, since it was a maritime hegemonic power at that time, Britain was likely to no longer put forward a similar sea power theory; otherwise, it would put its maritime hegemony on the path toward a deep recession. Similarly, after the World War II, the US exclusively dominated the world, surpassed the Britain, and considered as the maritime hegemonic power. Therefore, it was inappropriate to continue with the sea power theory. The US took part in the two World Wars in order to prevent the great powers of Eurasia from controlling the marginal regions. At that time, America's national interests and inter-state conflicts extended all over Eurasia.

Through the critical geopolitics interpretation of four classical Geopolitical Theories, this study has provided further evidence of three significant characteristics as specified in critical geopolitics, namely, situationality, diversity of viewpoint, non-neutrality of value, discursive power relations and political connotation of the Geopolitical Theory. For specific analysis and interpretation, please see Table 3 .

\section{Discussion and implications}

Through the above analysis, we shall pay close attention to the theory-building process of classical Geopolitical Theory, comprehensively understand the ontology, epistemology, methodology and axiology of Geopolitical Theory, and especially restore the historicality, sociality, situationality and power - knowledge structure of Geopolitical Theory, but we shall not be limited to or restricted to its conclusion or some remarks. Marx pointed out that, if the manifestation and nature of things could be directly combined into one, all of sciences would become superfluous (Marx et al., 1971). It is of great significance in gaining enlightenment from construction of peaceful geopolitical strategies under the background of rising China.

Firstly, in combination with the development of critical geopolitics, as can be seen from the analysis of this paper, there is no so-called eternal truth in classical Geopolitical Theory. The theory construction depends on the international pattern, national conditions, theory builders and other factors. The direction for theoretical construction is determined by spatial distribution of national interests, national strength, geographical conflicts between States and short-board effect of state power. Currently, our national strength ranks the second in the world, while the short-board effect of state power is considered as naval power. Although our national interests are distributed all over the world, the geographical conflicts between States are mainly concentrated in China's neighboring countries. Meanwhile, China is a country of both land and sea. Therefore, construction of geo-strategy for China's peaceful rise in the future shall take this as a starting point. 
Table 3 Summary of classical geopolitical theory based on a critical perspective

\begin{tabular}{|c|c|c|c|c|}
\hline & Land power theory & Sea power theory & $\begin{array}{c}\text { National organism } \\
\text { theory }\end{array}$ & Edge district theory \\
\hline $\begin{array}{l}\text { Time of } \\
\text { proposal }\end{array}$ & 1904 & 1898 & 1896 & 1944 \\
\hline $\begin{array}{l}\text { Author / } \\
\text { country }\end{array}$ & Mackinder / UK & Mahan / US & Ratzel / Germany & Speakman / US \\
\hline $\begin{array}{l}\text { Background } \\
\text { of author } \\
\text { Discipline } \\
\text { background } \\
\end{array}$ & $\begin{array}{l}\text { Geographer } \\
\text { Political scientist }\end{array}$ & $\begin{array}{l}\text { Naval historian } \\
\text { Navy strategist }\end{array}$ & $\begin{array}{l}\text { Geographer } \\
\text { Having received } \\
\text { specialized training } \\
\text { in biology }\end{array}$ & $\begin{array}{l}\text { Geopolitical strategist } \\
\text { International relation } \\
\text { scholar }\end{array}$ \\
\hline $\begin{array}{l}\text { Viewpoint / } \\
\text { concept }\end{array}$ & $\begin{array}{l}\text { Political geography is } \\
\text { based on the natural } \\
\text { geography. }\end{array}$ & Might is right. & $\begin{array}{l}\text { The social organic } \\
\text { system is similar to } \\
\text { the biological organ- } \\
\text { ism, subject to the } \\
\text { laws of nature. }\end{array}$ & $\begin{array}{l}\text { Geographical deter- } \\
\text { minism }\end{array}$ \\
\hline
\end{tabular}

Along with the economic development and population naval strength will contribute to the imScientificity The sea power is subject to the land forces. provement of national strength and the protection of overseas trade security. growth, the country needs more land to maintain the economic and population growth.
A great naval power needs to fight against land powers with the help of land bridgehead countries.

\begin{tabular}{|c|c|c|c|c|}
\hline Hypothesis & $\begin{array}{l}\text { On account of its ex- } \\
\text { pansion to the edge } \\
\text { zone of Eurasia, the } \\
\text { pivotal country can } \\
\text { create a fleet by taking } \\
\text { advantage of the huge } \\
\text { continental resources, } \\
\text { so that then the world is } \\
\text { in sight. }\end{array}$ & $\begin{array}{l}\text { In the final analysis, } \\
\text { since it has secured the } \\
\text { absolute command of } \\
\text { sea and has built the } \\
\text { most powerful navy, } \\
\text { the state will become } \\
\text { stronger and more } \\
\text { prosperous. }\end{array}$ & $\begin{array}{l}\text { There are seven laws } \\
\text { of national spatial } \\
\text { growth. }\end{array}$ & $\begin{array}{l}\text { Whether in wartime or } \\
\text { in peacetime, the US } \\
\text { must prevent several } \\
\text { power centers from } \\
\text { uniformly linking up } \\
\text { against its interests. }\end{array}$ \\
\hline Historicality & $\begin{array}{l}\text { Hundred Years' Great } \\
\text { Cold War between } \\
\text { Britain and Russia } \\
\text { Russian expansion in } \\
\text { Europe and Asia }\end{array}$ & $\begin{array}{l}\text { Surge in overseas trade; } \\
\text { interception of the US } \\
\text { Merchant Marine by } \\
\text { British Royal Navy in } \\
\text { the early days; trade } \\
\text { embargo during the } \\
\text { Napoleonic Wars; }\end{array}$ & $\begin{array}{l}\text { National united war, } \\
\text { instability of eco- } \\
\text { nomic growth and } \\
\text { continuous growth of } \\
\text { population }\end{array}$ & $\begin{array}{l}\text { Experiences of the } \\
\text { United States in enter- } \\
\text { ing the World War I \& } \\
\text { II }\end{array}$ \\
\hline $\begin{array}{l}\text { Sociality / } \\
\text { situationality }\end{array}$ & $\begin{array}{l}\text { The Great Britain was } \\
\text { actively expanding } \\
\text { overseas, establishing } \\
\text { its colonies, and striving } \\
\text { for hegemony all over } \\
\text { the world. }\end{array}$ & $\begin{array}{l}\text { The United States was } \\
\text { wandering between } \\
\text { conservative isolation- } \\
\text { ism and aggressive } \\
\text { overseas expansion. }\end{array}$ & $\begin{array}{l}\text { The unstable eco- } \\
\text { nomic growth and } \\
\text { continuous popula- } \\
\text { tion growth of Ger- } \\
\text { many would put the } \\
\text { tremendous pressure } \\
\text { on its living space. }\end{array}$ & $\begin{array}{l}\text { The America's GDP } \\
\text { share of the world's } \\
\text { total GDP was up to } \\
\text { nearly } 30 \% \text {. The } \\
\text { United States com- } \\
\text { pletely dominated the } \\
\text { world in the economy } \\
\text { and military. }\end{array}$ \\
\hline $\begin{array}{l}\text { Political } \\
\text { pursues } \\
\text { Value tar- } \\
\text { gets }\end{array}$ & $\begin{array}{l}\text { Serve the British over- } \\
\text { seas colonial expansion } \\
\text { and world hegemony. }\end{array}$ & $\begin{array}{l}\text { Enhance the naval } \\
\text { strength; expand the } \\
\text { overseas trade and } \\
\text { colonies; ensure the } \\
\text { maritime transport } \\
\text { security; }\end{array}$ & $\begin{array}{l}\text { Enhance the interna- } \\
\text { tional status of Ger- } \\
\text { many; implement the } \\
\text { imperialism and } \\
\text { "world politics". }\end{array}$ & $\begin{array}{l}\text { Adapt to the American } \\
\text { strategic vision of } \\
\text { postwar world hegem- } \\
\text { ony. }\end{array}$ \\
\hline $\begin{array}{l}\text { Geographic } \\
\text { knowledge - } \\
\text { power }\end{array}$ & $\begin{array}{l}\text { The pivotal country has } \\
\text { its nature of overseas } \\
\text { expansion and aggres- } \\
\text { sion as described above. } \\
\text { All other countries } \\
\text { should be united against } \\
\text { the pivotal country. }\end{array}$ & $\begin{array}{l}\text { The United States has } \\
\text { the basic conditions for } \\
\text { building up a strong } \\
\text { navy. }\end{array}$ & $\begin{array}{l}\text { The national system } \\
\text { is similar to the bio- } \\
\text { logical organism, } \\
\text { subject to the laws of } \\
\text { nature. Therefore, the } \\
\text { nation's expansion is } \\
\text { inevitable. }\end{array}$ & $\begin{array}{l}\text { The great power in the } \\
\text { Eurasian region has its } \\
\text { nature of expansion } \\
\text { and control of marginal } \\
\text { regions. }\end{array}$ \\
\hline
\end{tabular}


Secondly, as can be seen from a global scale, the US has not only built up its advantageous geopolitical pattern under its powerful economic and military backgrounds, but also controlled the main maritime transport hub. Nevertheless, the goal of China's peaceful rise is to neither dominate the world nor strive for hegemony with the US. This determines the difference between China's future peaceful geo-strategy and classical Geopolitical Theory. We consider that, faced with the facts that the US will strengthen its strategic alliance with neighboring countries of China after returning to the Asia-Pacific, China should adopt "cold treatment" in order to strengthen economic, social and cultural cooperation with its neighboring countries. Meanwhile, by excavating the Carat Strait Canal \& Nicaragua canal and modifying the Pan-Asia Railway and other infrastructures, we can weaken the control of the US over the maritime strategy passage so as to take the initiative to strengthen China's own national maritime transport security $\&$ protection.

Finally, this paper has also proved the correctness of "OBAO (One Belt and One Road)" strategy currently put forward by China. The "OBAO (One Belt and One Road)" strategy refers to a geo-strategy for building peaceful development, mutual benefit and win-win by strengthening economic exchanges between States. This can not only avoid world hegemony and head-on confrontation with the US, but also prevent any geopolitical containment of China when the US "returns to the Asia-Pacific" by building a three-dimensional traffic network of land, sea and air. It is conducive to the formation of "community of interest" and "community of destiny" between States. This is fully consistent with the analysis in the abovementioned two points.

Entering the new century, China is in a crucial period of great rejuvenation of the Chinese nation and national comprehensive development. Faced with the extremely complex and volatile international environment, we shall strengthen our theoretical study of geopolitical environment; these studies are of great value, both in theory and in practice, for the formulation of national rejuvenation, security and development strategies. In recent years, Chinese geographers have begun to strengthen their study of geopolitics; relevant units have established geopolitical research centers. However, currently, we have excessively placed particular stress on technical and empirical research, without attaching sufficient importance to theoretical research. Compared with other sub-disciplines related to human geography, the development of geopolitics as a main research direction of political geography has significantly lagged behind (Hu et al., 2013). Our geographers shall seize the opportunity to strengthen research on geopolitics and make greater contributions to China.

\section{References}

Anderson B, 2010. Morale and the affective geographies of the war on terror. Cultural Geographies, 17(2): 219-236.

Boland A, 2000. Feeding fears: Completing discourses of interdependency, sovereignty and China's food security. Political Geography, 19(1): 55-76.

Brzezinski Z, 2012. Big Chess: U.S. Primacy and Its Geopolitical Strategy. Shanghai: Shanghai People's Publishing House. (in Chinese)

Carter S, McCormack D, 2006. Geopolitics, film, and the affective logics of intervention. Political Geography, 25(2): 228-245.

Chen Yugang, Zhou Chao, Qin Qian, 2012. Critical geopolitics and the development of geopolitics at the South Pole. 
World Economics and Politics, (10): 116-131. (in Chinese)

Cosgrove D, 2008. Geography is everywhere: Cultural and symbolism in human landscapes. In: Greogry D, Walford R (eds.). Horizons in Human Geography. London: Palgrave Macmillan.

Dalby S, 1991a. American security discourse: The persistence of geopolitics. Political Geography, 9(2): 171-188.

Dalby S, 1991b. Critical geopolitics: Discourse, difference, and dissent. Environment and Planning D: Society and Space, 9(3): 261-283.

Dalby S, 2010. Recontextualising violence, power and nature: The next twenty years of critical geopolitics. Political Geography, 29(5): 280-288.

Ding Zeming, 2001. The American History: The American Civil War and the Gilded Age, 1861: The End of the 19th Century. Beijing: People's Publishing House (in Chinese)

Dodds K, 2001. Political geography III: Critical geopolitics after ten year. Progress in Human Geography, 25(3): 469-484.

Dodds K, 2007. Steve Bell's eye: Cartoons, popular geopolitics and the war on terror. Security Dialogue, 38(2): $157-177$.

Dodds K, Atkinson D, 2000. Geopolitical Traditions: A Century of Geopolitical Thought. London: Routledge.

Du Debin, Ma Yahua, 2012. Geography of containment and anti-containment of China's peaceful rise. World Regional Studies, 21(1): 1-16. (in Chinese)

Fenster T, 1996. Ethnicity and citizen identity in planning and development for minority groups. Political Geography, 15(5): 405-418.

Gachechiladze R, 1997. National idea, state-building and boundaries in the post-Soviet space (the case of Georgia). GeoJournal, 43(1): 51-60.

Ge Hanwen, 2010a. The development of critical geopolitics and geopolitical research in the future. International Review, (4): 42-48. (in Chinese)

Ge Hanwen, 2010b. Rethinking and reconstruction of geopolitics. Journal of Nanjing University, (6): 86-89. (in Chinese)

Hepple L, 1986. The revival geopolitics. Political Geography Quarterly, 5(4): s21-s36.

Hu Zhiding, Cao Yuan, Liu Yuli et al., 2013. A new development of political geography research in China: Geo-setting. Human Geography, 28(5): 123-128. (in Chinese)

$\mathrm{Hu}$ Zhiding, Ge Yejing, Xu Jianwei et al., 2012. Space and the construction of economic geography. Progress in Geography, 31(6): 211-216. (in Chinese)

$\mathrm{Hu}$ Zhiding, Luo Huasong, Ge Yuejing, 2014. Research perspectives of classical geopolitical theories and the enlightenment for developing China's new geopolitical theory. Tropical Geography, 34(2): 184-190. (in Chinese)

Huang Fengzhi, Jin Xin, 2012. The dilemma and innovation of theory of geopolitics. International Forum, 14(3): 1-6. (in Chinese)

Hyndman J, 2010. The question of 'the political' in critical geopolitics: Querying the 'child soldier' in the 'war on terror'. Political Geography, 29: 247-255.

Jones L, Daniel S, 2010. New directions in critical geopolitics: An introduction. GeoJournal, 75(4): 315-325.

Kissinger H A, 2012. Big Diplomacy. Hainan: Hainan Press. (in Chinese)

Li Gongzhen, 2005. Deutsche Road: Modernization Study. Hubei: Wuhan University Press. (in Chinese)

Luke T, Ó Tuathail G, 1997. On videocameralistics: The geopolitics of failed state, the CNN International and (UN) governability. Review of International Political Economy, 4(4): 709-733.

Luo Dadao, Du Debin, 2013. Some thoughts on the strengthening of geopolitical and geoeconomic studies. Acta Geographica Sinica, 68(6): 723-727. (in Chinese)

Mackinder H J, 2011. The Geographical Pivot of History. Beijing: The Commercial Press. (in Chinese)

Mahan A T, 2006. The Influence of Sea Power upon History. Beijing: The People's Liberation Army Press. (in Chinese)

Marcus P, David C, 2010. The state of critical geopolitics. Political Geography, 29(6): 243-246.

Marshall P J, 2004. The Cambridge Illustrated History of the British Empire. Beijing: World Affairs Press.

Martin M, 2008. Reconsidering the concept of discourse for the field of critical geopolitics: Towards discourse as language and practice. Political Geography, 27(3): 322-338. 
Marx, Engles, 1971. The Corpora of Marx and Engles: Volume 20. Beijing: People's Publishing House.

Megoran, N, 2006. For ethnography in political geography: Experiencing and reimagining Ferghana Valley boundary closures. Political Geography, 25(3): 622-640.

Momtaz D, 1996. The United Nations and the protection of the environment: From Stockholm to Rio de Janeiro. Political Geography, 15(3): 261-272.

Murphy D, 1997. The Heroic Earth: Geopolitical Thought in Weimar Germany 1918-1933. Kent Ohio: Kent State University Press.

Ó Tuathail G, 1986. The language and nature of the new geopolitics: The case of US-EI Salvador relations. Political Geography Quarterly, (5): 73-85.

Ó Tuathail G, 1996. Critical Geopolitical: The Politics of Writing Global Space. London: Routledge.

Ó Tuathail G, 1999. Understanding critical geopolitics and risk society. In: Colin S Gray, Geoffrey Sloan. Geopolitics, Geography and Strategy. London: Frank Cass.

Ó Tuathail G, 2003. Just out looking for a fight: American affect and the invasion of Iraq. Antipode, 35(5): $856-870$.

Ó Tuathail G, Agnew J, 1992. Geopolitics and discourse: Practical geopolitical reasoning in American foreign policy. Political Geography, 11(2): 190-204.

Ó Tuathail G, Sinon Dalby, 1998. Rethinking Geopolitics. London and New York: Routledge.

Paasi A, 2000. Rethinking geopolitics. Environment and Planning D: Society and Space, 18(2): 282-284.

Paasi A, 2006. Texts and contexts in the globalizing academic marketplace: Comments on the debate on geopolitical remote sensing. Eurasian Geography and Economics, 47(2): 216-220.

Parker G, 1998. Geopolitics: Past, Present and Future. London: Croom Helm.

Pepper J, Jenkins A, 1985. The Geography of Peace and War. London: Croom Helm.

Pinkerton A, Dodds K, 2009. Radio geopolitics: Broadcasting, listening and the struggle for acoustic spaces. Progress in Human Geography, 33(1): 10-27.

Reuber P, 2000. Conflict studies and critical geopolitics: Theoretical concepts and recent research in political geography. GeoJournal, 50(1): 37-43.

Shapiro M, 2008. Cinematic Geopolitics. London: Routledge.

Sharp J, 2000. Condensing the Cold War: Reader's Digest and American Identity. Minneapolis: University of Minnesota Press.

Sidaway J D, 2009. Shadows on the path: Negotiating geopolitics on an urban section of Britain's South West Coast path. Environment and Planning D: Society and Space, 27(6): 1091-1116.

Spykman N J, 1965. The Geography of the Peace. Beijing: The Commercial Press. (in Chinese)

Stavrianos L S, 2005. The Global History: From Prehistoric to 21st Century. Beijing: Peking University Press.

Sun Xiangdong, 2006. Geopolitics: The perspective of postmodernism criticizes. Journal of University of International Relations, (1): 44-49. (in Chinese)

Wang Enyong, Wang Zhengyi, Lou Yaoliang et al., 2003. Geopolitics. Beijing: Higher Education Press. (in Chinese)

Wang Guoliang, 2003. The security environment around China and relative geopolitical strategies. World Regional Studies, 12(2): 100-105. (in Chinese)

Wang Yiwei, Tang Xiaosong, 2003. The tragedy of great power politics and the tragedy of international theory. Academics in China, (6): 259-268. (in Chinese)

Watts M, 1997. Black gold, white heat: State violence, local resistance and the national question in Nigeria. In: Pile S, Keith M (ed.). Geographies of Resistance. New York: Routledge.

Wood W B, Potts L L, 1996. The UN and migration: Falling behind. Political Geography, 15(3): 251-260.

Ye Jiang, Yin Xiang, 2008. Comparative analysis on the conception of power in realism and neo-liberal institutionalism. International Politics Quarterly, (1): 131-142. (in Chinese)

Zhang Jianhua, 2014. History of Russia. Beijing: People's Publishing House. (in Chinese)

Zhang Wenmu, 2007. The grow and decline of the relative geopolitical strength of Europe and America and enlightenment for the rise of China. World Economics and Politics, (7): 45-56. (in Chinese)

Zhang Yaoguang, 1996. Coastal areas and territorial seas and marine geopolitics strategies of China. Human Geography, 11(2): 43-46. (in Chinese) 